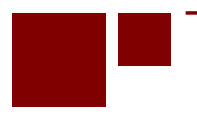

C E N T E R for RETIREMENT RES E A R C H at BOSTON COLLEGE

\title{
HOW DOES OCCUPATIONAL ACCESS FOR OLDER WORKERS DIFFER BY EDUCATION?
}

\author{
Matthew S. Rutledge, Steven A. Sass, Jorge D. Ramos-Mercado \\ CRR WP 2015-20 \\ August 2015 \\ Revised: August 2016
}
Center for Retirement Research at Boston College
Hovey House
140 Commonwealth Avenue
Chestnut Hill, MA 02467
Tel: 617-552-1762 Fax: 617-552-0191
http://crr.bc.edu

\begin{abstract}
All of the authors are with the Center for Retirement Research at Boston College (CRR). Matthew S. Rutledge and Steven A. Sass are research economists at the CRR. Jorge D. RamosMercado is a research associate at the CRR. The research reported herein was pursuant to a grant from the Alfred P. Sloan Foundation. The findings and conclusions expressed are solely those of the authors and do not represent the views of the Alfred P. Sloan Foundation or Boston College.

(C) 2016, Matthew S. Rutledge, Steven A. Sass, and Jorge D. Ramos-Mercado. All rights reserved. Short sections of text, not to exceed two paragraphs, may be quoted without explicit permission, provided that full credit, including (c) notice, is given to the source.
\end{abstract}




\begin{abstract}
About the Center for Retirement Research
The Center for Retirement Research at Boston College, part of a consortium that includes parallel centers at the University of Michigan and the National Bureau of Economic Research, was established in 1998 through a grant from the Social Security Administration. The Center's mission is to produce first-class research and forge a strong link between the academic community and decision-makers in the public and private sectors around an issue of critical importance to the nation's future. To achieve this mission, the Center sponsors a wide variety of research projects, transmits new findings to a broad audience, trains new scholars, and broadens access to valuable data sources.
\end{abstract}

Center for Retirement Research at Boston College

Hovey House

140 Commonwealth Ave

Chestnut Hill, MA 02467

Tel: 617-552-1762 Fax: 617-552-0191

http://crr.bc.edu

Affiliated Institutions:

The Brookings Institution

Massachusetts Institute of Technology

Syracuse University

Urban Institute 


\begin{abstract}
To assess the employment opportunities of older job-changers in the years prior to retirement, this study examines how the breadth of occupations in which they find employment narrows as they age past their prime working years and how this differs by gender and educational attainment. The results indicate that workers who change jobs in their early 50s find employment in a reasonably similar set of occupations as prime-age workers, with opportunities narrowing at older ages. They also indicate that job opportunities broadened significantly for better-educated older workers since the late 1990s. While job opportunities now narrow significantly for less-educated men in their late 50s, this narrowing primarily occurs in the early 60s for women and better-educated men. In contrast to previous research, the study finds that employer policies that emphasize hiring from within are less important barriers to the hiring of older job-seekers. The study also finds that the narrowing of job opportunities is associated with a general decline in job quality as measured by median occupational earnings, a decline associated with differences in occupational skill requirements and the underlying economic environment. These results suggest that older hiring is not as limited to a select few occupations as it had been in previous decades, but that policy reforms aimed at increasing opportunities and improving labor market fluidity would be best served to focus on less-educated men.
\end{abstract}




\section{Introduction}

Job-changing after age 50 is increasingly common. In 1983, 70 percent of men ages 5862 were still working full-time for their age 50 employer. That figure fell to 44 percent by 2012. ${ }^{1}$ The ability of older job-changers to find suitable employment affects not just their current income. It also affects their ability to remain employed long enough to secure an adequate retirement income. One measure of the ability to find suitable employment is the range of occupations in which older job-seekers find jobs. A series of papers by Hutchens (1986, 1988, 1991, 1993) shows that employment opportunities for job-seekers age 55 and older were concentrated in a select set of occupations during the early 1980s. This study builds on Hutchens' research by investigating: 1) the extent to which job opportunities continue to be restricted for workers age 50 to 64 in a more recent period (1996-2012); 2) whether the extent of restriction differs by age and between better- and less-educated workers; and 3) how access changed between 1996 and 2012.

The results indicate that workers who change jobs in their early 50s find employment in a somewhat comparable set of occupations as prime-age workers. Job-changers in their early 60s, however, find employment in an increasingly narrow set of occupations. Less-educated men see their opportunities narrow even earlier: in their late 50s.

The results also indicate a change over time. At the beginning of the period under review, employment options were more restricted for better-educated older workers, relative to the options available to better-educated prime-age workers. Employment opportunities for older workers then generally expanded, especially for better-educated workers ages 55 to 64 . Differences by education at any given age are now generally small, except for the difference between better- and less-educated men in their late 50s. Differences by gender are now much greater at all ages, with employment opportunities narrowing much more for men as they age past their prime working years.

The analysis then identifies labor market characteristics associated with the narrowing of employment opportunities. In contrast to earlier findings in Hutchens $(1986,1988)$ and Hirsch, Macpherson, and Hardy (2000), it finds that "internal labor market” policies that respect seniority and promote from within seem less important than in the past. Factors such as active learning, numerical ability, and physical skills are associated with less hiring of older workers,

\footnotetext{
${ }^{1}$ Munnell and Sass (2008) and authors’ calculations using Current Population Survey data.
} 
while occupations that value dependability and working outdoors hire relatively greater shares of workers at age 50 and beyond.

Finally, the study considers the consequences of this narrowing of employment opportunities, using median occupational earnings as the yardstick for job quality. Without accounting for differences in the jobs' characteristics, occupations that hire greater shares of older workers appear to pay about 6-7 percent less; better-educated workers lose even more, about 7-12 percent less. But the difference in pay fades to nothing after controlling for factors such as internal labor market arrangements, the underlying economic environment, and the tasks and skills associated with the job.

On the whole, these results suggest some hopefulness for older workers. Though their job options narrow with age, that narrowing has slowed nearly across the board. And even for occupations that are still "old-people jobs," the pay level is no different than at jobs with more equal shares of older and prime-age hires. The one exception to this optimism is less-educated men in their late 50s, whose job opportunities have not improved over time. These results suggest that policy reforms aimed at further improving the fluidity of the job market - such as improved job training, career counseling, and assistance with searching for a job - would be best served to focus on less-educated men.

\section{Previous Literature}

The study of older workers’ job opportunities begins with Hutchens (1986, 1988, 1991, 1993), who finds that the older job-changers found employment in relatively few occupations, with most occupations hiring very few older workers. These studies attribute much of this narrowing of employment opportunities to “internal labor market” policies that employers established for managing and developing their workforce, such as hiring from within and respect for seniority, as well as DB pensions and mandatory retirement. These policies protect older employees, but create barriers to entry for older job-seekers. Hutchens uses the fact that many older employees were working in occupations where few were hired as evidence that older workers were willing and able to do the work. These occupations are associated with long tenures, high wages for older workers, DB pensions, and mandatory retirement, which Hutchens uses as evidence that employers’ internal labor market policies - and not worker preferences and abilities - were largely responsible for this narrowing of employment opportunities. 
Subsequent research has largely confirmed Hutchens' findings while expanding the list of factors that reduce access to employment by older job-seekers. Hirsch, Macpherson, and Hardy (2000) provide additional evidence that internal labor markets created significant impediments to the employment of job-seekers age 50 and over through most of the 1990s. They also find occupations that require extensive training, computer use, numerical aptitude, and union membership were also less open to older job-seekers, with hiring concentrated in "old person" occupations - low-paying, low-status jobs such as night watchman, retail clerk, or crossing guard. Other researchers find age discrimination also reduces hiring opportunities (Lahey 2006; Neumark and Song 2013). Adler and Hilber (2009) finds that job-seekers ages 55 to 64 in 2005 were disproportionately hired in growing industries, in industries that do not pay older workers significant earnings premiums (consistent with the findings of Hutchens and Hirsch et al.), and pay newly hired older workers less than the older workers they already employ.

Opportunities for older job-seekers today might not be as bleak as they were in the 1980s and early 1990s. Internal labor markets, which Hutchens cites as major impediments to their employment, seem less significant in a more fluid "knowledge-based" economy that emphasizes generic, as opposed to firm-specific, human capital (Karoly and Panis 2004; Osterman 2011). Older workers are also much better educated than they were in the 1980s and are no longer less educated than younger workers (Munnell and Sass 2008). Educated job-seekers, who possess more generic human capital and longer expected work-lives, should be more attractive to employers. Older workers also make up a much larger share of the labor force. After the first Baby Boomers turned 50, in 1996, the ratio of workers under age 50 to those over age 50 fell from 4:1 in 1995 to 2:1 today. Older workers likely account for a greater share of supervisors and human resources professionals who make the hiring decisions, and are likely to be more favorably disposed toward older job candidates than younger supervisors and HR professionals (Munnell, Sass, and Soto 2006). Since the displacement of older workers shows no upward trend - at least until the Great Recession (Farber 2015) - the rise in job-changing also seems largely due to quits, not layoffs (Munnell and Sass 2008). While displaced older workers generally see large wage reductions in their new jobs (Chan and Stevens 2004), older job-changers who separated voluntarily generally do not (Johnson and Kawachi 2007). Along with the growing prevalence of job-changing, workers are also retiring later, suggesting that older job-changers are finding “suitable” employment opportunities (Munnell 2015). 
This study extends the Hutchens-style analysis in several directions. It only examines job-changing by workers age 50 to 64 , assessing employment opportunities prior to the traditional retirement age of 65; this departs from Hutchens, Hirsch et al., and Johnson and Kawachi, which assess re-employment opportunities for all older workers - even those well past conventional retirement ages. Second, it tests the hypothesis that hiring opportunities narrow with age and are increasingly concentrated in low-paying occupations. Third, it examines the effect of gender and education, testing the hypotheses that opportunities decline at a different pace for older job-changers that differ by education and gender. Fourth, it examines a more recent time period, when the well-educated Baby Boom generation swelled the ranks of older workers, when older workers became a larger share of the labor force, and when the nation moved toward a more fluid knowledge-based economy, testing the hypothesis that the cumulative effect of these changes expanded access to employment opportunities for older workers. Fifth, it assesses the contribution of occupational skill requirements and working conditions in explaining the narrowing of employment opportunities as workers age.

\section{Data and Sample}

The aim of the study is to assess the extent to which occupational employment opportunities narrow as job-changers age past their prime working years, defined as ages 30 to 49, and how this varies by educational attainment and gender. The basic unit of the analysis is the occupation. Over the period under review, we count up the number of workers hired in that occupation by age, education, and gender. We also collect occupational characteristics, including compensation, turnover and tenure, required skills, and work conditions, to identify factors associated with changes in occupational access.

The analysis uses data on hiring within occupations and worker characteristics from the Current Population Survey (CPS), sponsored jointly by the U.S. Census Bureau and the U.S. Bureau of Labor Statistics. The CPS surveys respondents on a monthly basis eight times over a 16-month window and also fields regular supplementary surveys. The monthly survey provides information on the worker's age, occupation, gender, and education. Our outcome variable of interest - workers recently hired in a particular occupation - relies on data from the Occupational Mobility and Job Tenure supplement, collected biennially in January or February. Our sample uses observations from this supplement in nine even-numbered years between 1996 
and 2012, which are available on the Integrated Public Use Microdata Series (IPUMS) website (King et al. 2010). The longer the time since the worker was hired, the greater the likelihood the worker changed jobs within that employer. To reduce this source of error in identifying hiring by occupation, the analysis restricts the sample to workers hired within the five years that preceded the job tenure supplement. ${ }^{2}$

The sample is divided by education and gender, with educational attainment split between workers who have, or don't have, at least some college experience. This divides the sample into four roughly equal gender and education sub-groups. We identify hiring using threedigit occupations, the lowest level of aggregation available in the CPS, when the sample includes at least 20 prime-age workers of a given education and gender combination hired in that occupation. Three-digit occupations that do not have 20 prime-age hires are aggregated at the two-digit level. For example, if 24 less-educated prime-age men were hired as messengers, a three-digit occupation, across the years surveyed, messengers would be included in the sample without further aggregation. If only nine less-educated prime-age men were hired as postal clerks and 11 as mail clerks outside the postal service, these two occupations, with a total of 20 prime-age hires, would be combined at the two-digit level as "mail and message distributing occupations, not elsewhere classified.”

When the sample is divided by gender and education, it has 2,172 gender- and educationspecific occupation cells, compiled from 315 unique occupations with a sufficient number of prime-age hires. This sample includes 83 percent of the original sample of older hires, missing hiring in only a few small occupations. Table 1 presents the number of occupations in each cell with a sufficient number of prime-age workers and the share of workers of a particular age, gender, and education level included in these occupations. Sample sizes decline when the sample is further divided into groups defined by gender and education or is divided into three time periods to assess change over time (1996-2000, 2002-2006, and 2008-2012). For example, only 230 occupations have enough prime-age better-educated men to be included in the sample for better-educated older workers; these 230 occupations, however, account for about 60 percent of the older, better-educated men in the CPS sample.

\footnotetext{
${ }^{2}$ Hutchens $(1988,1991)$ and Hirsch et al. (1999) also use a five-year window. The age of hiring is the worker's age less their tenure with their employer, and their current occupation is assumed to be the occupation in which they were hired.
} 
The CPS also provides data on occupational characteristics used in the analysis, such as the occupation's 10-year employment growth and the national unemployment rate. Other characteristics derive from the Annual Social and Economic Characteristic supplement, which is fielded each March. From this supplement, we calculate each occupation's median earnings (by age, gender, and education); the share of employees in each occupation working full-time, parttime voluntarily, and part-time involuntarily; median employer size; and the proportion with a pension and in a union. ${ }^{3}$ The Occupational Mobility and Job Tenure supplement also provides information on the share of workers in the occupation with lengthy tenures, defined as 15 or more years of tenure, and the turnover rate, defined as the share of workers with less than five years of tenure. This information is used to identify employer personnel policies that may restrict employment opportunities for older job-seekers, as seen in Hutchens $(1986,1988)$ and Hirsch et al. (2000).

The O*NET database, produced by the U.S. Department of Labor's Employment and Training Administration in conjunction with the North Carolina Department of Commerce, provides further information on the required skills that could affect the ability of older jobseekers to find employment in a particular occupation, as used by Hirsch et al. (2000). For each occupation, O*NET provides scores for the importance of a particular skill and the level of skill required. We calculate the product of the two scores for 59 skills, organized into 14 categories: active learning, communication, judgment, education, experience, training requirements, working outdoors, social skills, math skills, strength, physical skills, computer skills, dependability, and exposure to hazards. ${ }^{4}$

\section{Methodology}

To assess the extent to which employment opportunities narrow, the project compares the share of older job-changers to the share of prime-age job-changers hired in each occupation. We compare the pattern of occupational hiring: 1) by age; 2) by education and gender; and 3) over time. Regression analysis identifies factors associated with hiring differences, such as employer

\footnotetext{
${ }^{3} \mathrm{DB}$ pension coverage is a useful indicator of internal labor markets and therefore an important barrier to the employment of older job-seekers (Hutchens 1986, 1988; Hirsch et al. 2000). The CPS, however, does not specify whether pensions are DB plans or defined contribution (DC) plans.

${ }^{4}$ The two scores - importance and level of skill required - are both normalized so that they vary over a range from 0 to 1 . While the O*NET database includes scores for thousands of minutely-defined skills, we use only 59, aggregated into these 14 categories.
} 
personal practices, skill requirements, and working conditions. Finally, we compare earnings in occupations with large and small share of older workers as a measure of the effect of occupational access on the quality of employment opportunities available to older job-seekers.

The key variable in the analysis is the occupational hiring ratio, $O H_{j}$, originally specified by Hutchens (1988 and 1991). $O H_{j}$ is defined as the ratio of the share of older job-changers hired in occupation $j$ to the share of prime-age job-changers hired in occupation $j$ :

$$
\text { OH }_{j}=\frac{\frac{\text { HireOld }_{j}}{\sum_{j} \text { HireOld }_{j}}}{\frac{\text { HirePrime }_{j}}{\sum_{j} \text { HirePrime }_{j}}}
$$

$\frac{\text { HireOld }_{j}}{\sum_{j} \text { HireOld }_{j}}$ is the share of older workers hired over the past five years in occupation $j$ as a percent of older workers hired in all occupations. $\frac{\text { HirePrime }_{j}}{\sum_{j} \text { HirePrime }_{j}}$ is the share of prime-age workers hired in occupation $j$. For example, assume 3 better-educated women age 50-54 were hired as veterinarians out of 2,995 college-educated women that age hired in all occupations combined. Veterinarians thus make up 3/2995 $=0.10$ percent of the workers hired in this age-educationgender group. Assume 24 prime-age better-educated women were hired as veterinarians, or 0.11 percent of 20,967 prime-age workers hired this education-gender group. The $O H$ ratio for veterinarians in this age, education, and gender combination is $0.10 / 0.11=0.88$.

A low ratio of older workers to prime-age workers hired indicates that a smaller share of older job-changers is hired in the occupation than prime-age job-changers; a high ratio indicates that the occupation hires a relatively large number of older workers. We take ratios between 0.75 and 1.25 to indicate that older workers have much the same access to employment in the occupation as prime-age workers. In contrast, occupations with hiring ratios of 2 or more could be classified as "old-person jobs" - jobs that hire older workers in substantially greater proportions than their hiring of prime-age workers.

Hiring ratios are calculated separately for each occupation for men and women with and without at least some college education; at ages 50-54, 55-59, and 60-64; and in years 1996-2012 and the sub-periods 1996-2000, 2002-2006, and 2008-2012. In each case, the denominator of 
$\mathrm{OH}_{j}$ is the share of prime-age workers of the same gender and educational attainment hired in the occupation in the same period, with at least 20 prime-age hires for each occupation included in the analysis.

We use these occupational hiring ratios to evaluate the distribution of job opportunities for older workers in two different ways. First, we use histograms to assess the extent to which hiring opportunities narrow for men and women with and without college experience as they age past their prime working years. We also report the change over time in the proportion of workers in "old-person jobs” for each of age group, and each group defined by education and gender. ${ }^{5}$

Following Hutchens (1991), we also use occupational hiring ratios to construct Lorenz Curves and calculate Gini coefficients that indicate the concentration of job opportunities in a subset of occupations as workers age. ${ }^{6}$ In this analysis, occupations are sorted according to their hiring ratios, from low to high. The Lorenz Curves then plot the cumulative share of older workers hired on the $y$-axis and the cumulative share of prime-age workers hired on the $\mathrm{x}$-axis. A perfectly equal share of hiring at both older ages and prime ages in all occupations would yield a "curve" on the 45-degree line. But when hiring is not equally distributed, the Lorenz Curve at first rises slowly, then more steeply at the right-hand end of the plot, indicating that hiring is concentrated in a subset of occupations.

The Gini coefficient is the ratio of the area between the Lorenz Curve and the 45-degree line to the entire area below the 45-degree line. The greater the concentration of hiring, the greater the gap between the Lorenz Curve and the 45-degree line, and the greater the Gini coefficient. The study calculates the Gini coefficient by estimating a regression of the cumulative share of older hires on a quadratic function of the cumulative share of prime-age hires. This estimation yields a fitted curve; the Gini coefficient is the ratio of the area between the 45-degree line and the fitted curve. ${ }^{7}$ Gini coefficients are calculated separately for each age group and by gender, education, and time period.

\footnotetext{
${ }^{5}$ We do not use CPS-provided weights, because the analysis stacks together multiple years. The regression analysis uses weights constructed from the number of respondents in the occupation.

${ }^{6}$ Lorenz Curves are most commonly used to assess income and wealth inequality. See Kennickell (2009) for a survey.

${ }^{7}$ The estimation that produces the fitted curve also produces a confidence interval for that curve, allowing for hypothesis testing of whether the fitted curve is statistically different from the 45-degree line. The fitted curve is constrained to start at $(0,0)$ and end at $(1,1)$.
} 
The histograms show the share of workers hired in occupations within a given range of hiring ratios. The share of workers hired in occupations with hiring ratios between 0.75 and 1.25 indicate the persistence of job opportunities, as it indicates the share of workers hired in occupations that hire approximately equal shares of older and prime-age job-changers. If access narrows, this "persistence share" will fall and Gini coefficient will rise. We use these measures to test whether employment opportunities narrow at a faster pace as job-seekers age; whether occupational access evolves differently by gender and educational attainment; and whether these patterns have changed over time.

The project also identifies factors associated with differences in occupational access by estimating regressions using occupational hiring ratios as the dependent variable. ${ }^{8}$ The explanatory variables include: 1) proxies for the importance of internal labor markets: the share of the occupation's workforce with more than 15 years of tenure and the turnover rate (the ratio of hires to all employees); 2) the importance of specific skills based on the O*NET variables; 3) macroeconomic indicators of labor market strength; 4) indicators that previous research suggests reflect worker preferences: the share of the occupation's workforce that works part-time and typical working conditions; 5) the importance of other institutional structures, such as median firm size and the share of the occupational workforce that is unionized; 6) compensation, including the log of median occupational earnings and the share with pension coverage (DB and DC combined); and 7) age, education, and gender, to examine how occupational hiring ratios vary by these characteristics.

In an alternative specification of the regression, we include the occupational employment ratio, a measure that is analogous to the hiring ratio, except that it includes all workers, not just recent hires. The occupational employment ratio, $O E_{j}$, compares the share of all older workers employed in an occupation to the share of all prime-age workers employed in the occupation, irrespective of tenure:

\footnotetext{
${ }^{8}$ In the regression, each observation is weighted by that occupation's total hires over age 50 . Weighting assures that occupations that have a greater share of the labor market also have a greater influence on the estimation.
} 


$$
O E_{j}=\frac{\frac{\text { Older Workers }_{j}}{\sum_{j} \text { Older Workers }_{j}}}{\text { Prime Workers }_{j}}
$$

This is similar to measures used in Hutchens $(1986,1988)$ and Hirsch et al. (2000) to control for labor supply - the size of the pool of individuals who are willing and able to work in a given occupation - to help identify the effect of employer policies on the employment opportunities of older job-changers.

Finally, the project examines whether the narrowing of occupational access affects the quality of employment opportunities, using median occupational hourly wages of workers ages 30-64 as the measure of occupational quality. The analysis estimates two regression models where the natural logarithm of this wage measure is the dependent variable. The vector of independent variables consists of the hiring ratio and all of the occupation-level variables from the hiring ratio regression, plus period dummies. The resulting coefficient is the change in the hourly wages for a typical occupation associated with a one-percentage-point increase in its hiring ratio - for example, an all-else-equal comparison of an occupation that hires equal shares of older and prime-age workers to an occupation with a share of older hires that is exactly twice its share of prime-age hires. The hypothesis in the earnings regression is that occupations disproportionately hiring older workers pay less than occupations with relatively equal shares of prime-age and older hires.

\section{Results}

The key variable in the analysis is the occupational hiring ratio, which is used to measure the degree to which employment opportunities across occupations become more limited as workers age past their prime working years. The analysis first plots histograms of hiring ratios for older job-changers by gender, education, and age. It then lists occupations where hiring is more and less accessible to older workers, and the largest occupations where access is similar to that of prime-age workers. Next, we quantify the degree to which hiring is concentrated using Gini coefficients, and examine how this measure has changed over time. We then estimate regressions that identify the factors associated with employment opportunities. Finally, we 
determine whether occupations favorable disposed toward older hiring are less desirable using median earnings as an indicator of desirability.

Table 2 reports the summary statistics for the hiring ratios by age, gender, and education, weighted by the number of older workers from each subgroup in each occupation. The mean hiring ratio is close to one for the age groups that combine genders and educations (top panel), as expected. The median hiring ratio is somewhat lower than one for workers ages 60-64, because 20 percent of occupations hire exactly zero workers in our sample from this age group (i.e., a hiring ratio of 0 ). The mean ratio is slightly above one for most of the gender-education subgroups; we do not recombine occupations with fewer than 20 prime-age workers from these subgroups, so the fact that the ratio exceeds one suggests that occupations with fewer prime-age workers are somewhat more likely to have low ratios, as expected. On the whole, the mean hiring ratio increases with age for men, but not for women. The hiring ratio is largest for bettereducated women at 50-54 and 55-59, and for less-educated men at 55-59 and 60-64.

\section{More and Less Accessible Occupations for Older Job-Changers}

What kinds of jobs are most open to older workers as they age, which are most closed, and which are relatively indifferent to the age of the job-seeker? Table 3 lists the top five and bottom five occupations, ranked by hiring ratio; this ranking includes all occupations in which at least two older workers in the sample are hired in each group. Some of the occupations identified in Hirsch et al. (2000) that tend to skew older appear in this list, including tailors, taxi drivers guards and watchmen, and dressmakers and seamstresses. Only older workers are left to fill vacancies in occupations in long-term decline, such as farmers. Sales demonstration, on the other hand, is a growing occupation apparently suited to older workers.

Among the occupations listed that rarely hire older workers, some involve physical labor, including metal workers, fishermen, roofers, and glaziers (glass-fitters). Other occupations require workers to keep up with improving technology, such as medical scientists and electrical technicians. In addition, some occupations, such as railroad conductors, display internal labor market characteristics, such as long tenures and enforced or encouraged early retirement on DB pensions. 


\section{Employment Opportunities Narrow with Age}

Figure 1 displays the histogram of this ratio for men with and without college experience (across the columns) in each age group: 50-54, 55-59, and 60-64, respectively. For men of both education levels in their early 50s, just over half are hired in occupations that hire a similar share of prime-age job-changers. While some hiring occurs in occupations that disproportionately hire older workers, as identified in earlier studies, only 5 percent are in occupations with hiring ratios greater than 2.

At older ages, hiring increasingly shifts to occupations that disproportionately hire older workers. The share of better-educated men in their late 50s hired in occupations with ratios near one is 43 percent, down somewhat from the share in their early 50s (59 percent). For lesseducated men ages 55-59, this share falls even further, to 38 percent, indicating a greater narrowing of hiring opportunities for less-educated men in their late 50s than for better-educated men. In their early 60s, however, similar shares of better- and less-educated men are hired in occupations with hiring ratios greater than $2-20$ and 22 percent, respectively.

Figure 2 repeats this analysis for women. A clear majority of women in their early 50s are hired in jobs with relatively equal opportunities for older and prime-age workers; in particular, 72 percent of less-educated female hires are in jobs with ratios near one, a substantially greater share than men at these ages. As with men, employment prospects become somewhat more limited for women in their late-50s, but the share with ratios near one decline by less: from 57 percent to 45 percent for better-educated women, and from 72 percent to 59 percent for less-educated women. Both groups of women look similar in their early 60s, with the proportion with ratios near one falling to 38 percent of better-educated women and 42 percent of less-educated women, and the shares with ratios of 2 or greater increasing to 14 percent and 10 percent, respectively. Still, opportunities decline less for women than for men as they age past their prime working years.

\section{Measuring the Concentration of Older Hiring by Occupation}

The Lorenz curves in Figure 3 for the three age groups - ages 50-54, 55-59, and 60-64 provide further evidence of narrowing job opportunities as workers age. The Lorenz curves move further from the 45-degree line with age, indicating an increasing concentration of hiring in a smaller number of occupations. 
The Gini coefficients in the first three rows of Table 4 quantify the increasing concentration of hiring particular occupations as workers age. At ages 50-54, the Gini coefficient is 0.10 , a level that is low, but statistically distinct from zero. ${ }^{9}$ The Gini rises - and the concentration of hiring increases - to 0.16 at ages 55-59 and to 0.29 at 60-64. The confidence interval around each Gini is compact, so each increase is statistically significant.

Figures 4 and 5 plot Lorenz curves for men and women, respectively, by education level. Table 4 reports the Gini coefficients for each Lorenz curve. The Lorenz curves and Gini coefficients show similar trends: hiring concentration rises with age in all four worker groups. Among men, between ages 50-54 and 55-59, the Gini rises from 0.20 to 0.29 for more-educated men, and slightly more for less-educated men, from 0.22 to 0.32 . At ages 60-64, the concentration of hiring is similar for men in both of the educational groups. Hiring opportunities narrow less for women, and especially for less-educated women in their 50s. At ages 60-64, however, the concentration of hiring becomes similar for women in both of educational groups. However, hiring opportunities are clearly more limited for men in their early 60s, relative to opportunities for prime-age men, with Gini coefficients of just over 0.4 , as opposed to 0.3 for women that age. ${ }^{10}$

\section{Hiring Concentration over Time}

Table 5 reports Gini coefficients for each subgroup across three different time periods 1996-2000, 2002-2006, and 2008-2012. ${ }^{11}$ The Gini coefficients generally declined over time, indicating a broadening of employment opportunities for older job-changers.

In the late 1990s, Gini coefficients were larger for men than for women, and while men's Ginis are similar by education, less-educated women had lower Gini coefficients at each age than more-educated women. Furthermore, the age pattern differed by gender: while Ginis increased with age in lockstep for better- and less-educated men, employment opportunities narrowed more quickly for better-educated women than for their less-educated counterparts.

\footnotetext{
${ }^{9}$ For comparison, no country's income distribution has a Gini coefficient of less than 0.20 going back to 2006 (World Bank 2015). The lowest Gini coefficient for a U.S. state's income distribution on record - going back to 1917 - is 0.23 for Arizona in 1921 (Frank 2015).

${ }^{10}$ The Gini coefficients for the groups separated only by age (the first three rows) are not a weighted average of the subgroups defined by gender and education because the number of occupations that are large enough for inclusion varies across the groups. Similarly, the all-period Gini coefficients are not a weighted average of the period-specific Ginis because of decreasing sample size.

${ }^{11}$ The histograms plotted by time period tell a similar story to the Gini coefficients.
} 
By the late 2000s, however, Gini coefficients had fallen for all groups. The one exception is less-educated men in their late 50s, though men with a high school degree or less saw declining Gini coefficients at ages 50-54 and 60-64. In contrast, better-educated men saw across-the-board improvement in the breadth of employment opportunities. As a result, the Ginis of better- and less-educated men are similar at 50-54 and 60-64, but employment opportunities are much narrower for less-educated men at ages 55-59.

Compared to men, women saw much larger decreases in Gini coefficients between the late 1990s and late 2000s. The declines were especially large for better-educated women, almost closing the gap with less-educated women in each age group. This decline likely reflects a cohort effect - that older educated women increasingly had similar professional qualifications as prime-age women. In each period, women's Gini coefficients are smaller than those for men of the same education group and age, indicating less of a narrowing of job options for older women job-seekers.

The general trend toward broader occupational employment opportunities differs from the results reported in Hirsch, et al. (2000). That study finds little improvement, albeit over an earlier time period and for a population of “older workers" that includes individuals age 65 and over, many of whom presumably find employment in "retirement jobs." The broadening of opportunities is consistent with a decline in the importance of internal labor markets. That the broadening of opportunities was largely concentrated among better-educated workers is also consistent with the well-documented increase in earnings inequality and a skill-biased shift in labor demand. That better-educated workers are the primary beneficiaries of changes in the labor-market for older workers suggest that they reflect a shift to a more fluid, knowledge-based economy, with generic human capital - which better-educated workers tend to possess becoming increasingly important relative to firm-specific human capital employers developed and retained using internal labor market policies.

\section{Identifying the Correlates of Occupational Access}

The above analysis indicates that job options become more limited with age, though the reduction in opportunities has grown less severe over time. But to which types of jobs are older workers limited? Table 6 reports estimates of the regression of the occupational hiring ratio on various characteristics of the occupation, the employer, and work arrangements. The first two 
columns report summary statistics for the full sample (ages 30-64). The middle two columns report estimates where the dependent variable in the regression is the occupational hiring ratio for each age-gender-education combination. The rightmost columns add the occupational employment ratio as a control for labor supply. The unit of observation is the occupation-agegender-education cell.

The first variables seek to identify the relationship between internal labor markets and hiring ratios: occupational turnover rates and the incidence of long tenures. Both turnover rates and the proportion of an occupation's workforce with tenure of 15 years or longer are associated with lower hiring ratios - meaning less hiring of older workers - though only the turnover rate is statistically significant. We also find no difference in the likelihood that older workers are hired in occupations that are heavily unionized. This differs from Hirsch et al. (2000), which finds union jobs are less available to older workers. Our result could reflect the shift in the composition of union membership from industrial unions, in industries such as autos and steel that are characterized by long tenures with a single employer, to craft unions, in industries such as the building trades that often involve relatively short tenures with a succession of employers.

The regression estimates do show that occupations with high pension coverage rates have lower hiring ratios. Hutchens (1988) and Hirsch et al (2000) used pension coverage as an indicator of internal labor markets, as pension coverage at the time was almost entirely in DB plans. Our result indicates that pension coverage is still associated with lower hiring of older workers even in a 401(k) world. ${ }^{12}$ While this is consistent with the continued importance of internal labor markets, our other results indicate that internal labor markets are much less of a barrier to older hires than in the past - the negative and statistically significant correlation with job turnover rates, and the statistical insignificance of long tenures and union coverage.

The next set of variables in Table 6 accounts for the skills necessary to perform an occupation's duties, as derived from the O*NET database. Some of the results are surprising: occupations hiring greater shares of older workers relative to prime-age workers require greater strength and working outdoors. ${ }^{13}$ The relationship between hiring ratio and most other characteristics are in the expected direction. For example, dependability is associated with greater hiring of older workers as expected (but in contrast to the summary statistics), while the

\footnotetext{
12 The CPS does not distinguish between defined benefit and defined contribution pension plans.
}

${ }^{13}$ Hirsch et al (2000) also found this relationship with working outdoors, though not with strength. 
counterintuitive results for communication skills, judgment, training, social skills, computer skills, and exposure to hazards all fade to statistical insignificance. As expected, and in keeping with the summary statistics, occupations requiring active learning, numerical ability, and physical skills are hire fewer older workers.

The next set of variables accounts for the economic environment in which workers are changing jobs. Employment growth in an occupation over the previous 10 years is associated with a statistically significant increase in hiring ratios. But, even though the coefficients look large, the low mean (in the first column) indicates that employment growth is low for most occupations, so this variable has only a small correlation with the hiring ratio. Hirsch et al. (2000) likewise find no evidence of a relationship between occupational employment growth and hiring ratios. The national unemployment rate is statistically insignificantly related to the hiring ratio. Smaller firms with 0-24 or 25-99 employees are less likely than firms with 100 or more employees to hire older workers, which could reflect greater sensitivity to the higher cost of health insurance for older workers.

Hiring ratios may also reflect worker preferences, with older workers seeking jobs with particular characteristics. Hirsch et al. (2000) found evidence that older women seek part-time employment, raising hiring ratios in occupations characterized by significant part-time work. We find that the association between hiring ratios and part-time work differs substantially by whether the part-time arrangement occurs voluntarily. Hiring ratios are positively associated with the share of workers who are part-time voluntarily, which implies that “old-people jobs” with high hiring ratios serve, to some degree, as bridge jobs. But hiring ratios are negatively correlated with the share of workers who are part-time involuntarily which, like the employment growth coefficient, implies that occupations with high hiring ratios are in stronger industries.

When we control for labor supply using the occupational employment ratio, the share of older workers employed in the occupation, the relationship between hiring ratios and the other variables tested is essentially unaffected. The coefficient on the occupational employment ratio itself is statistically insignificant and small: a doubling of the mean occupational employment ratio would be associated with only a 0.11-percentage-point decrease in the occupational hiring ratio. This weak result indicates either that the occupational employment ratio is a poor proxy for labor supply, or that labor demand drives most of the differences in the hiring of older workers. 
The regression also tests whether the occupational hiring ratio differs by age, gender, and education as suggested by Table 2, after controlling for these factors. Hiring ratios are statistically significantly greater for workers age 60-64 and for men. The difference by education, however, is not statistically significant. These results corroborate not only Table 2, but also the results from the histograms and the Gini coefficients.

Overall, the regression results suggest that older workers are less impeded by internal labor markets than in the past, and that more jobs are open to voluntary part-time work. Most skills associated with greater hiring of older workers - greater dependability; less need for active learning, numerical skills, or physical skills - fit our expectations. “Old-people jobs” also appear to be in strong industries with employment growth and little involuntary part-time work.

\section{Comparing Earnings by Occupations’ Older Hiring}

One surprising result reported in Table 6 is that occupations that disproportionately hire older workers pay higher median hourly wages (for all recent hires ages 30-64), all else equal. Table 7 examine further how the positive correlation comes about. This table reports the estimated coefficient on the occupational hiring ratio in regressions where wages are the dependent variable, without and with controlling for other occupational characteristics. The unit of observation is the occupation-age-gender-education-period cell.

The first row reports the estimates for the full sample. The coefficient in the first column, for the regression without controls, is negative and statistically significant - indicating that occupations that disproportionately hire older workers pay less - though the correlation is small. The gap is smaller and not statistically significant for workers at ages 50-54, but larger and statistically significant for all workers at 55-59 and 60-64; for better-educated workers of all ages and both genders; and for less-educated workers at ages 55-59 and 60-64. Only two groups see statistically significantly greater pay in “old-people jobs” - less-educated workers of both genders at ages 50-54. On the whole, however, the results in the first column indicate that "oldpeople jobs” with a hiring ratio of 2 pay about 6-12 percent less than jobs that hire equal shares of older and prime-age workers.

But the estimates in the first column do not take into account that the jobs that have greater hiring ratios differ substantially from occupations with lower ratios, as shown in Table 6. The next column adds occupation-level controls that account for these differences. The 
coefficients on the hiring ratio become smaller, and actually flip signs, though they remain statistically insignificant for the three main age groups. With controls, no subgroup has a statistically significant negative estimate.

These results indicate that occupations that disproportionately hire older workers to pay less, but that this correlation is entirely attributable to differences in the underlying characteristics of the jobs in which older workers find employment. In particular, controlling for the O*NET skill requirements makes the negative association between hiring ratio and hourly wages fade to zero, or even become positive for some subgroups (better-educated men and women at ages 60-64). The estimates with the occupation-level controls suggests that the skills and tasks - such as active learning, numerical ability, and physical skills - are not skills and tasks that employers see - correctly or otherwise - in older job-seekers.

\section{Conclusion}

A generation ago, older workers approaching retirement were unlikely to change jobs. Today, over half of all workers change jobs in their 50s. The availability of employment opportunities for such job-changers has become increasingly important as workers need to extend their careers to compensate for falling Social Security replacement rates and the decline of DB pensions.

The paper updates research on the previous generation of older workers, primarily Hutchens (1986, 1988) and Hirsch et al. (2000), by focusing on job-changing between the ages of 50 and 64, and examining how the evolution of employment opportunities differs by gender and educational attainment. We find that workers in their early 50s have relatively similar job opportunities as prime-age workers, but the occupations available to older job-seekers thereafter narrows for both better- and less-educated workers. In the late 1990s, better-educated workers saw their occupation choices decline more rapidly with age than less-educated workers.

Occupations have since become more open to older job-changers, with better-educated workers the primary beneficiaries and less educated men in their late 50s the primary exception. By the end of the period under review, access to occupations narrowed significantly for lesseducated men in their late 50s - but not until the early 60s for better-educated men and for women in both education groups. The main divide in occupational access became gender, not education: men saw their employment opportunities narrow more as they aged past their prime- 
working years - with this difference primarily driven by the difference in occupational access between less-educated men and women.

The results indicate that the importance of internal labor markets has weakened with the decline in union power and the decline of career employment in large-scale enterprises. The results largely agree with other work that dependability and, somewhat surprisingly, working outdoors are associated with greater opportunities for older workers, while active learning, numerical ability, and physical skills limit job options for workers after turning 50.

The results confirm earlier notions that the narrowing of employment opportunities is associated with a general decline in job quality, as indicated by median occupational wages. Occupations that disproportionately hire older workers pay somewhat lower wages than occupations that hire relatively equal shares of older and prime-age workers. But the gap in earnings by hiring ratio is entirely explained by differences in skill requirements and the capabilities of older workers - at least as perceived by employers.

These results should be interpreted with caution. Most importantly, the sample included only job-seekers that found employment - not those who failed. As such, it provides a rosier picture of the labor market prospects for older workers, especially during the Great Recession. Since less-educated workers are far more likely to drop out of the labor force in their 50s, this caveat is especially true for less-educated older job-seekers. 


\section{References}

AARP. 2005. American Business and Older Employees: a Focus on Midwestern Employers. Washington, DC: AARP.

Adler, Geri and Don Hilber. 2009. "Industry Hiring Patterns of Older Workers.” Research on Aging 31(1): 69-88.

Autor, David and David Dorn. 2009. “This Job is 'Getting Old’: Measuring Changes in Job Opportunities Using Occupational Age Structure.” American Economic Review Papers and Proceedings 99(2): 45-51.

Chan, Sewin and Ann Huff Stevens. 2004. "How Does Job Loss Affect the Timing of Retirement?” Contributions to Economic Analysis and Policy 3(1): 1-24.

Farber, Henry S. 2015. "Job Loss in the Great Recession and its Aftermath: U.S. Evidence from the Displaced Workers Survey.” Working Paper 21216. Cambridge, MA: National Bureau of Economic Research.

Frank, Mark W. 2015. “U.S. State-Level Income Inequality Data.” Huntsville, TX. Available at: http://www.shsu.edu/eco_mwf/inequality.html.

Hirsch, Barry T., David A. Macpherson, and Melissa A. Hardy. 2000. “Occupational Age Structure and Access for Older Workers.” Industrial and Labor Relations Review 53(3): 401-418.

Hutchens, Robert M. 1986. "Delayed Payment Contracts and a Firm’s Propensity to Hire Older Workers.” Journal of Labor Economics 4(4): 439-457.

. 1988. “Do Job Opportunities Decline with Age?” Industrial and Labor Relations Review 42(1): 89-99.

. 1991. "Segregation Curves, Lorenz Curves, and Inequality in the Distribution of People across Occupations.” Mathematical Social Sciences 21(1): 31-51.

1993. "Restricted Job Opportunities and the Older Worker.” In As the Workforce Ages: Costs, Benefits and Policy Challenges, edited by Olivia S. Mitchell, 81-102. Ithaca, NY: ILR Press.

2006. "Job Opportunities for Older Workers: When Are Jobs Filled With External Hires?” Andrew Mason and Mitoshi Yamaguchi, eds., Population Change, Labor Markets, and Sustainable Growth: Towards a New Economic Paradigm. Amsterdam: Elsevier. 
Johnson Richard W. and Janette Kawachi. 2007. "Job Changes at Older Ages: Effects on Wages, Benefits, and Other Job Attributes.” Working Paper 2007-4. Chestnut Hill, MA: Center for Retirement Research at Boston College.

Karoly, Lynn A. and Constantijn W. A. Panis. 2004. The 21st. Century at Work: Forces Shaping the Future Workforce and Workplace in the United States. Santa Monica, CA: RAND Corporation.

Kennickell, Arthur B. 2009. "Ponds and Streams: Wealth and Income in the U.S., 1989 to 2007.” Finance and Economics Discussion Paper 2009-13. Washington, DC: Federal Reserve Board of Governors.

King, Miriam, Steven Ruggles, J. Trent Alexander, Sarah Flood, Katie Genadek, Matthew B. Schroeder, Brandon Trampe, and Rebecca Vick. 2010. Integrated Public Use Microdata Series, Current Population Survey: Version 3.0. Minneapolis, MN: University of Minnesota.

Lahey, Joanna N. 2006. “Do Older Workers Face Discrimination?” Issue in Brief 33. Chestnut Hill, MA: Center for Retirement Research at Boston College.

Munnell, Alicia H. 2015. “The Average Retirement Age: An Update.” Issue in Brief 15-4. Chestnut Hill, MA: Center for Retirement Research at Boston College.

Munnell, Alicia H. and Steven A. Sass. 2008. Working Longer. Washington, DC: Brookings Institution Press.

Munnell, Alicia H., Steven A. Sass, and Mauricio Soto. 2006. "Employer Attitudes Towards Older Workers: Survey Results.” Work Opportunities for Older Workers, Series 3. Chestnut Hill, MA: Center for Retirement Research at Boston College.

Neumark, David and Joanne Song. 2013. “Do Stronger Age Discrimination Laws Make Social Security Reforms More Effective?” Journal of Public Economics 108: 1-16.

Osterman, Paul. "Institutional labor economics, the new personnel economics, and internal labor markets: a reconsideration." Industrial \& Labor Relations Review 64(4): 637-653.

Sanzenbacher, Geoffrey T., Steven A. Sass, April Yanyuan Wu, and Christopher M. Gillis. 2016 (forthcoming). "The Effect of Job Mobility on Retirement Timing by Education.” Working Paper. Chestnut Hill, MA: Center for Retirement Research at Boston College.

Willis, Robert J. 2013. "The Cognitive Demands of Work and the Length of Working Life: The Case of Computerization.” Discussion Paper 13-015. Stanford, CA: Stanford Institute for Economic Policy Research.

World Bank. 2015. “GINI Index (World Bank Estimate).” Washington, DC. Available at: http://data.worldbank.org/indicator/SI.POV.GINI. 
Table 1. Sample Size for Occupation Groups Defined by Age, Sex, and Education

\begin{tabular}{lcc}
\hline & Number of occupations & Percent of older hires included \\
\hline All & 315 & $82.5 \%$ \\
Men with some college or more & 230 & 60.2 \\
Men with no college & 189 & 49.5 \\
Women with some college or more & 179 & 46.9 \\
Women with no college & 178 & 46.6 \\
\hline
\end{tabular}

Note: Inclusion in the sample requires at least 20 prime-age hires.

Source: Current Population Survey Occupational Mobility and Job Tenure Supplements, 1996-2012. 
Table 2. Summary Statistics of Occupational Hiring Ratios by Age, Gender, and Education

\begin{tabular}{lccc}
\hline Cohort & Mean & Median & Std dev \\
\hline $50-54$ & 1.019 & 0.997 & 0.383 \\
$55-59$ & 1.007 & 0.943 & 0.541 \\
$60-64$ & 1.038 & 0.850 & 0.854 \\
\hline Men & & & \\
\hline Overall & 1.135 & 0.981 & 1.080 \\
College & & & \\
$50-54$ & 1.028 & 1.003 & 0.648 \\
$55-59$ & 1.062 & 0.938 & 0.846 \\
$60-64$ & 1.123 & 0.683 & 1.310 \\
No college & & & \\
$50-54$ & 1.148 & 1.003 & 0.979 \\
$55-59$ & 1.230 & 0.986 & 1.229 \\
$60-64$ & 1.284 & 1.001 & 1.376 \\
\hline Women & & & \\
Overall & 1.138 & 1.051 & 0.951 \\
College & & & \\
$50-54$ & 1.387 & 1.294 & 0.808 \\
$55-59$ & 1.375 & 1.320 & 1.033 \\
$60-64$ & 1.198 & 1.019 & 1.305 \\
No college & & & \\
$50-54$ & 1.079 & 1.086 & 0.821 \\
$55-59$ & 0.901 & 0.875 & 0.660 \\
$60-64$ & 0.929 & 0.791 & 0.874 \\
\hline
\end{tabular}

Source: Current Population Survey Occupational Mobility and Job Tenure Supplements, 1996-2012. 
Table 3. Top and Bottom 10 Occupations Ranked by Occupational Hiring Ratio

\begin{tabular}{lrrr}
\hline & Older hires & Prime hires & OH ratio \\
\hline Top 10 occupations & & & \\
Sales demonstrators / promoters / models & 44 & 46 & 3.68 \\
Crossing guards and bridge tenders & 34 & 38 & 3.44 \\
Farmers (owners and tenants) & 143 & 195 & 2.82 \\
Guards, watchmen, doorkeepers & 404 & 641 & 2.42 \\
Taxi cab drivers and chauffeurs & 170 & 300 & 2.18 \\
Bus drivers & 293 & 535 & 2.11 \\
Dressmakers and seamstresses & 41 & 76 & 2.07 \\
Messengers & 80 & 149 & 2.06 \\
Protective services, n.e.c & 18 & 35 & 1.98 \\
Retail sales clerks & 722 & 1412 & 1.97 \\
Bottom 10 occupations & & & \\
Electrical and electronic technicians & 18 & 187 & 0.37 \\
Meter readers & 4 & 42 & 0.37 \\
Structural metal workers & 8 & 88 & 0.35 \\
Railroad conductors and yardmasters & 2 & 23 & 0.33 \\
Fishers, hunters, and kindred & 3 & 36 & 0.32 \\
Paper folding machine operators & 2 & 26 & 0.30 \\
Medical scientists & 8 & 122 & 0.25 \\
Roofers and slaters & 13 & 213 & 0.23 \\
Firefighting, prevention, and inspection & 5 & 99 & 0.19 \\
Glaziers & 2 & 46 & 0.17 \\
\hline
\end{tabular}

Source: Authors' estimates from the Current Population Survey, 1996-2012. 
Table 4. Gini Coefficients by Age, Sex, and Education

\begin{tabular}{|c|c|c|c|c|}
\hline & \multirow{2}{*}{$\begin{array}{c}\text { Gini } \\
\text { coefficient }\end{array}$} & \multicolumn{2}{|c|}{ Confidence interval } & \multirow{2}{*}{$\begin{array}{c}\text { Number of } \\
\text { occupations }\end{array}$} \\
\hline & & Lower & Upper & \\
\hline \multicolumn{5}{|l|}{ All } \\
\hline Age 50-54 & 0.095 & 0.090 & 0.100 & 315 \\
\hline Age 55-59 & 0.156 & 0.150 & 0.162 & 315 \\
\hline Age 60-64 & 0.228 & 0.220 & 0.236 & 315 \\
\hline \multicolumn{5}{|l|}{ Men } \\
\hline \multicolumn{5}{|c|}{ Some college or more } \\
\hline Age 50-54 & 0.199 & 0.194 & 0.200 & 230 \\
\hline Age 55-59 & 0.285 & 0.270 & 0.286 & 230 \\
\hline Age 60-64 & 0.401 & 0.379 & 0.403 & 230 \\
\hline \multicolumn{5}{|l|}{ No college } \\
\hline Age 50-54 & 0.216 & 0.205 & 0.217 & 189 \\
\hline Age 55-59 & 0.319 & 0.301 & 0.321 & 189 \\
\hline Age 60-64 & 0.427 & 0.398 & 0.430 & 189 \\
\hline \multicolumn{5}{|l|}{ Women } \\
\hline \multicolumn{5}{|c|}{ Some college or more } \\
\hline Age 50-54 & 0.161 & 0.155 & 0.161 & 179 \\
\hline Age 55-59 & 0.227 & 0.219 & 0.227 & 179 \\
\hline Age 60-64 & 0.308 & 0.297 & 0.309 & 179 \\
\hline \multicolumn{5}{|l|}{ No college } \\
\hline Age 50-54 & 0.153 & 0.147 & 0.153 & 178 \\
\hline Age 55-59 & 0.218 & 0.210 & 0.218 & 178 \\
\hline Age 60-64 & 0.305 & 0.296 & 0.306 & 178 \\
\hline
\end{tabular}

Source: Authors' calculations. 
Table 5. Gini Coefficients by Period, for Age, Sex, and Education Groups

\begin{tabular}{|c|c|c|c|c|c|c|}
\hline & \multicolumn{2}{|c|}{$1996-2000$} & \multicolumn{2}{|c|}{$2002-2006$} & \multicolumn{2}{|c|}{ 2008-2012 } \\
\hline & Gini & $\mathrm{N}$ & Gini & $\mathrm{N}$ & Gini & $\mathrm{N}$ \\
\hline \multicolumn{7}{|l|}{ All } \\
\hline Age $50-54$ & 0.140 & 247 & 0.114 & 250 & 0.095 & 222 \\
\hline Age 55-59 & 0.178 & 247 & 0.176 & 250 & 0.156 & 222 \\
\hline Age 60-64 & 0.284 & 247 & 0.249 & 250 & 0.228 & 222 \\
\hline \multicolumn{7}{|l|}{ Men } \\
\hline \multicolumn{7}{|c|}{ Some college or more } \\
\hline Age $50-54$ & 0.245 & 162 & 0.247 & 178 & 0.211 & 157 \\
\hline Age 55-59 & 0.322 & 162 & 0.337 & 178 & 0.291 & 157 \\
\hline Age 60-64 & 0.500 & 162 & 0.468 & 178 & 0.462 & 157 \\
\hline \multicolumn{7}{|l|}{ No college } \\
\hline Age $50-54$ & 0.258 & 127 & 0.266 & 132 & 0.227 & 124 \\
\hline Age 55-59 & 0.337 & 127 & 0.364 & 132 & 0.356 & 124 \\
\hline Age 60-64 & 0.531 & 127 & 0.464 & 132 & 0.46 & 124 \\
\hline \multicolumn{7}{|c|}{ Women } \\
\hline \multicolumn{7}{|c|}{ some college or more } \\
\hline Age 50-54 & 0.253 & 115 & 0.206 & 127 & 0.208 & 112 \\
\hline Age 55-59 & 0.343 & 115 & 0.242 & 127 & 0.275 & 112 \\
\hline Age 60-64 & 0.438 & 115 & 0.37 & 127 & 0.343 & 112 \\
\hline \multicolumn{7}{|l|}{ No college } \\
\hline Age $50-54$ & 0.201 & 141 & 0.213 & 135 & 0.195 & 112 \\
\hline Age 55-59 & 0.288 & 141 & 0.236 & 135 & 0.263 & 112 \\
\hline Age 60-64 & 0.435 & 141 & 0.356 & 135 & 0.342 & 112 \\
\hline
\end{tabular}

Source: Authors' estimates from the Current Population Survey, 1996-2012. 
Table 6. Summary Statistics and Estimates from Regression of Occupational Hiring Ratio on Occupational Characteristics

\begin{tabular}{|c|c|c|c|c|c|c|}
\hline & \multicolumn{2}{|c|}{ Summary statistics } & \multicolumn{2}{|c|}{$(1)$} & \multicolumn{2}{|c|}{$(2)$} \\
\hline & Mean & $\mathrm{SE}$ & Coef & $\mathrm{SE}$ & Coef & SE \\
\hline \multicolumn{7}{|l|}{ Internal labor market controls } \\
\hline Turnover rate & 0.572 & 0.083 & -2.362 & $0.886 * * *$ & -1.630 & $0.859+$ \\
\hline Share with $15+$ years of tenure & 0.141 & 0.047 & -0.689 & 1.424 & 0.105 & 1.377 \\
\hline Union coverage & 0.152 & 0.142 & -0.420 & 0.258 & -0.058 & 0.252 \\
\hline Pension coverage & 0.584 & 0.182 & -3.036 & $0.536 * * *$ & -1.649 & $0.534 * * *$ \\
\hline \multicolumn{7}{|l|}{ O*NET skills and tasks } \\
\hline Active learning & 0.493 & 0.223 & -0.983 & $0.420 * *$ & -0.552 & 0.407 \\
\hline Communication skills & 0.386 & 0.186 & 0.295 & 0.476 & -0.354 & 0.464 \\
\hline Judgment & 0.418 & 0.210 & -0.167 & 0.403 & -0.003 & 0.389 \\
\hline Education & 0.280 & 0.169 & 0.363 & $0.201+$ & -0.015 & 0.197 \\
\hline Experience & 0.423 & 0.201 & -0.006 & 0.140 & 0.037 & 0.135 \\
\hline Training & 0.310 & 0.205 & -0.404 & 0.286 & -0.135 & 0.277 \\
\hline Working outdoors & 0.395 & 0.156 & 0.941 & $0.383 * *$ & 0.772 & $0.370 *$ \\
\hline Social skills & 0.484 & 0.176 & -0.217 & 0.327 & 0.072 & 0.317 \\
\hline Numerical ability & 0.264 & 0.127 & -0.794 & $0.286 * * *$ & -0.593 & $0.277^{*}$ \\
\hline Strength & 0.187 & 0.176 & 2.758 & $0.582 * * *$ & 1.643 & $0.572 * * *$ \\
\hline Dependability & 0.651 & 0.169 & 1.076 & $0.221 * * *$ & 1.042 & $0.214^{* * *}$ \\
\hline Physical skills & 0.196 & 0.159 & -5.136 & $0.773 * * *$ & -3.220 & $0.768 * * *$ \\
\hline Computer skills & 0.174 & 0.180 & 0.207 & 0.233 & 0.329 & 0.226 \\
\hline Exposure to hazards & 0.397 & 0.065 & 0.707 & 0.557 & 0.272 & 0.540 \\
\hline \multicolumn{7}{|l|}{ Economic environment } \\
\hline 10-year growth in employment & 0.060 & 0.300 & 0.277 & $0.091^{* * *}$ & 0.306 & $0.088 * * *$ \\
\hline Unemployment rate & 6.055 & 0.090 & 0.137 & 0.290 & 0.355 & 0.281 \\
\hline Share of firms with $<24$ employees & 0.220 & 0.163 & -1.924 & $0.444 * * *$ & -1.160 & $0.435 * * *$ \\
\hline Share of firms with 25-99 employees & 0.114 & 0.032 & -1.924 & $0.873^{*}$ & -2.139 & $0.844 * *$ \\
\hline Log of real hourly earnings & 2.745 & 1.596 & 0.578 & $0.151 * * *$ & 0.602 & $0.145 * * *$ \\
\hline \multicolumn{7}{|l|}{ Labor supply } \\
\hline Share involuntary part time & 0.035 & 0.030 & -3.272 & $1.537^{*}$ & -1.191 & 1.497 \\
\hline Share voluntary part time & 0.158 & 0.080 & 1.039 & $0.437 * *$ & 1.064 & $0.422 * *$ \\
\hline Occupational employment ratio & 5.964 & 2.625 & & & -0.111 & 0.010 \\
\hline \multicolumn{7}{|l|}{ Demographics } \\
\hline Age $50-54(0 / 1)$ & 0.333 & 0.472 & 0.000 & 0.051 & 0.000 & 0.049 \\
\hline Age 60-64 (0/1) & 0.333 & 0.472 & 0.146 & $0.051 * * *$ & 0.146 & $0.049 * * *$ \\
\hline Male $(0 / 1)$ & 0.502 & 0.500 & 0.220 & $0.042 * * *$ & 0.220 & $0.040 * * *$ \\
\hline Some college or more $(0 / 1)$ & 0.508 & 0.500 & -0.058 & 0.041 & -0.060 & 0.040 \\
\hline Constant & & & 2.367 & 1.989 & -0.113 & 1.935 \\
\hline Sample size & & & 1605 & & 1605 & \\
\hline $\mathrm{R}^{2}$ & & & 0.175 & & 0.231 & \\
\hline Adjusted $\mathrm{R}^{2}$ & & & 0.160 & & 0.216 & \\
\hline
\end{tabular}


Table 7. Coefficients on Hiring Ratio in Regressions of Occupations' Hourly Wages

\begin{tabular}{lcc}
\hline & No controls & With controls \\
\hline Overall & $-0.04^{* * *}$ & $0.02^{*}$ \\
All workers & & \\
$50-54$ & 0.02 & 0.03 \\
$55-59$ & $-0.07^{* * *}$ & 0.01 \\
$60-64$ & $-0.06^{* * *}$ & 0.01 \\
\hline Men & & \\
\hline Some college education & & \\
$50-54$ & $-0.12^{* * *}$ & -0.02 \\
$55-59$ & $-0.08^{* * *}$ & 0.03 \\
$60-64$ & $-0.07^{* * *}$ & $0.03 * *$ \\
No college education & & \\
$50-54$ & $0.07 * * *$ & 0.04 \\
$55-59$ & $-0.07^{* *}$ & -0.01 \\
$60-64$ & $-0.07^{* * *}$ & -0.02 \\
\hline Women & & \\
\hline Some college education & & \\
$50-54$ & $-0.07^{* * *}$ & -0.02 \\
$55-59$ & $-0.11^{* * *}$ & 0.03 \\
$60-64$ & $-0.08^{* * *}$ & -0.01 \\
No college education & & $0.06 * * *$ \\
$50-54$ & $0.06 *$ & 0.03 \\
$55-59$ & -0.06 & \\
$60-64$ & -0.02 & \\
\hline
\end{tabular}

Source: Authors' calculations. 
Figure 1. Occupational Hiring Ratios for Older Men, By Age and Education

Some college education

No college education

Men 50 to 54 year olds
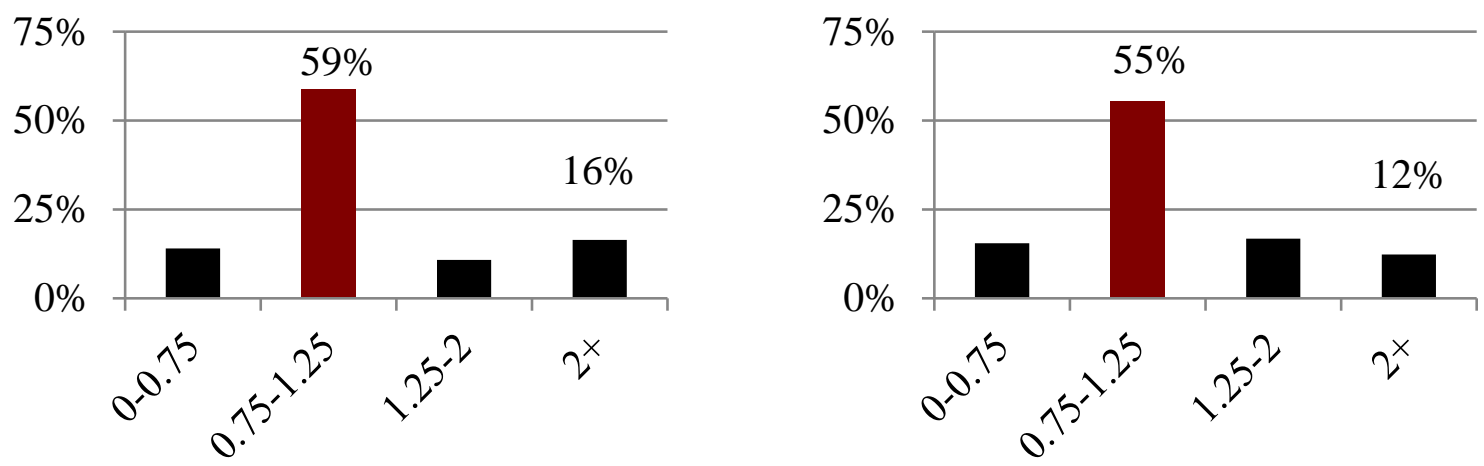

Men 55 to 59 year olds
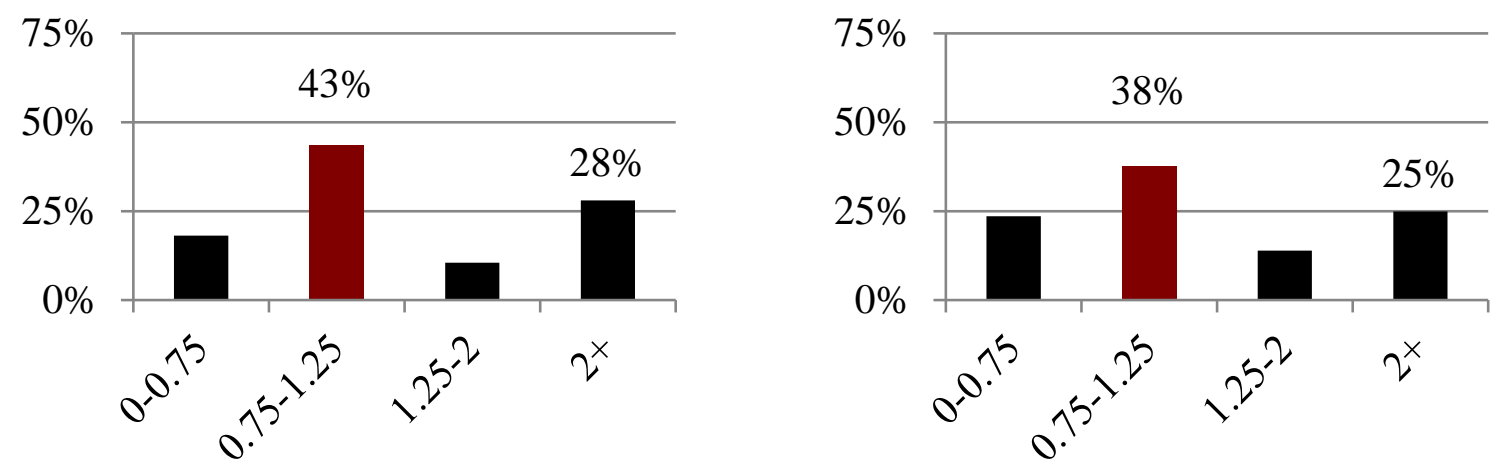

Men 60 to 64 year olds
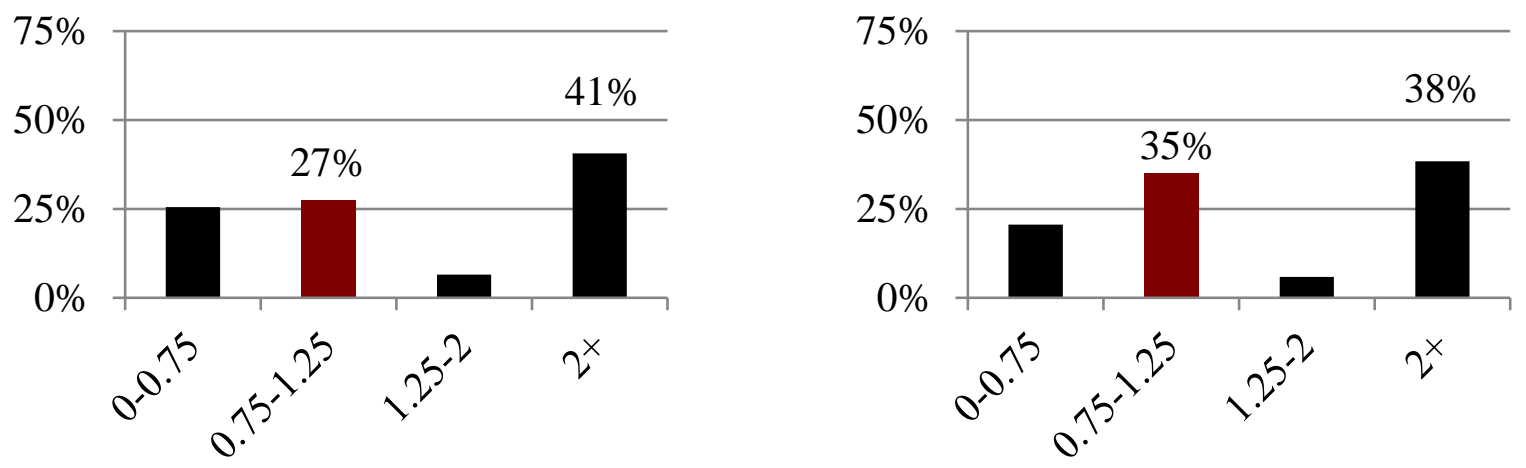

Source: Authors' calculations. 
Figure 2. Occupational Hiring Ratios for Older Women, By Age and Education

Some college education

No college education

Women 50 to 54 year olds
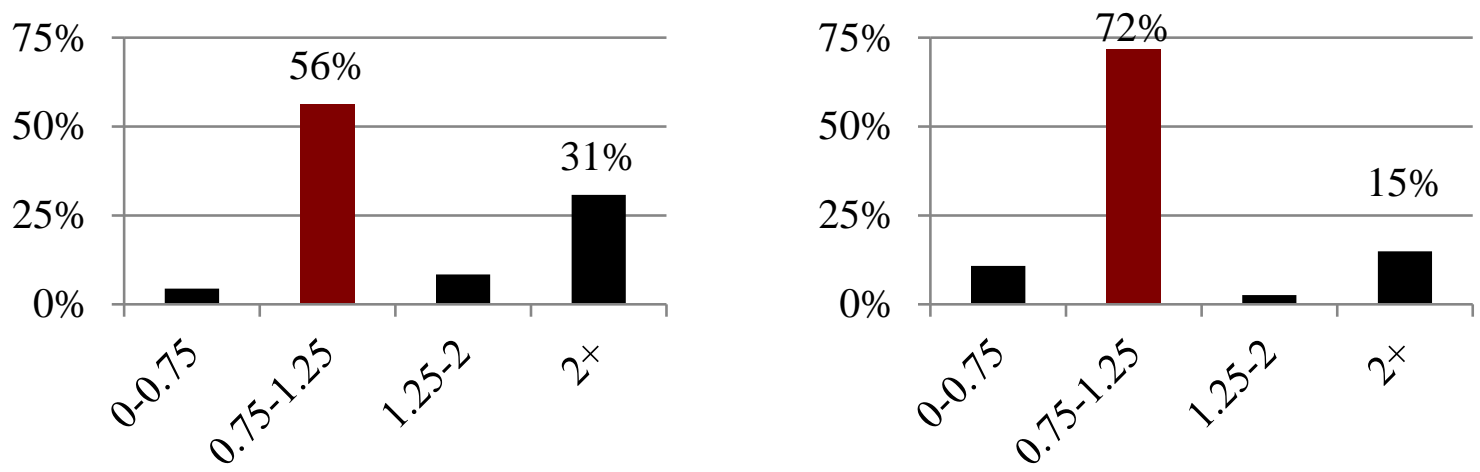

Women 55 to 59 year olds
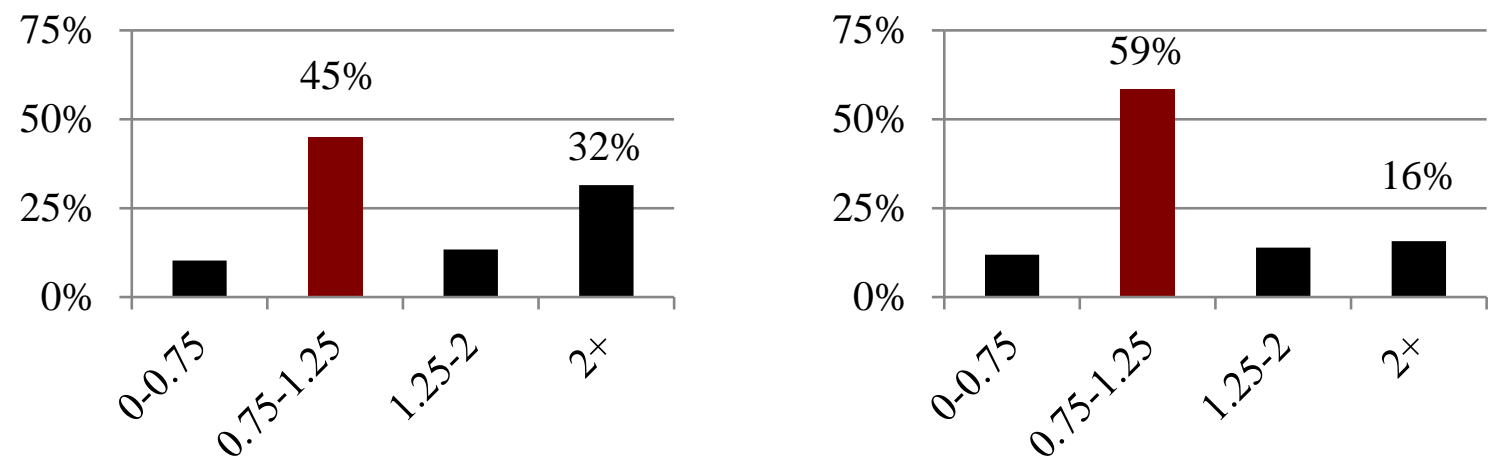

Women 60 to 64 year olds
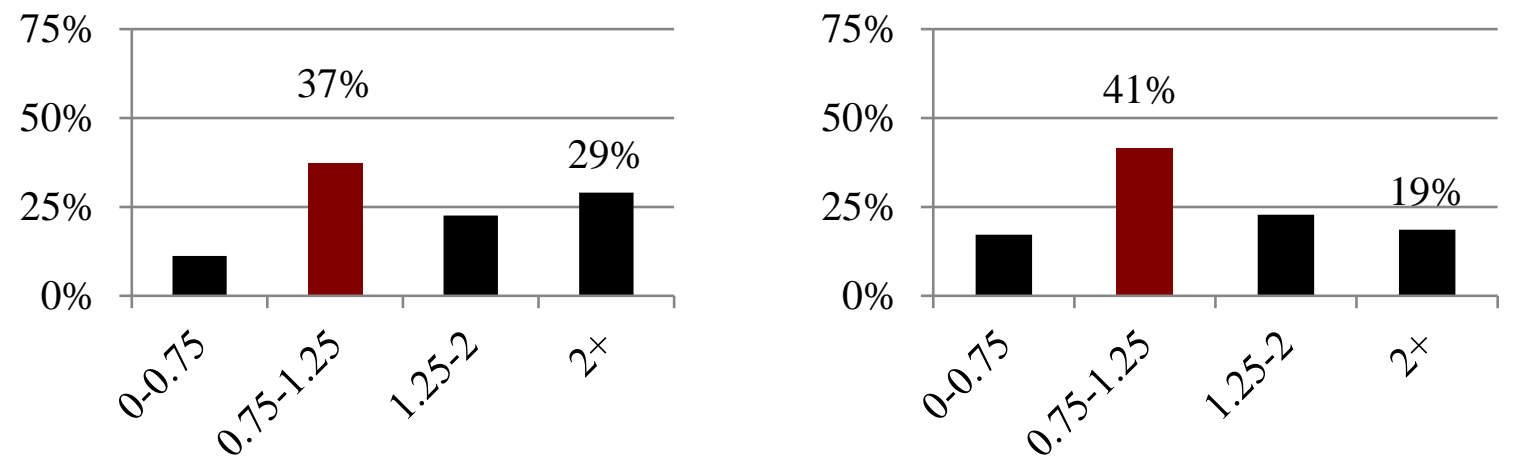

Source: Authors' calculations. 
Figure 3. Lorenz Curves by Age Cohorts

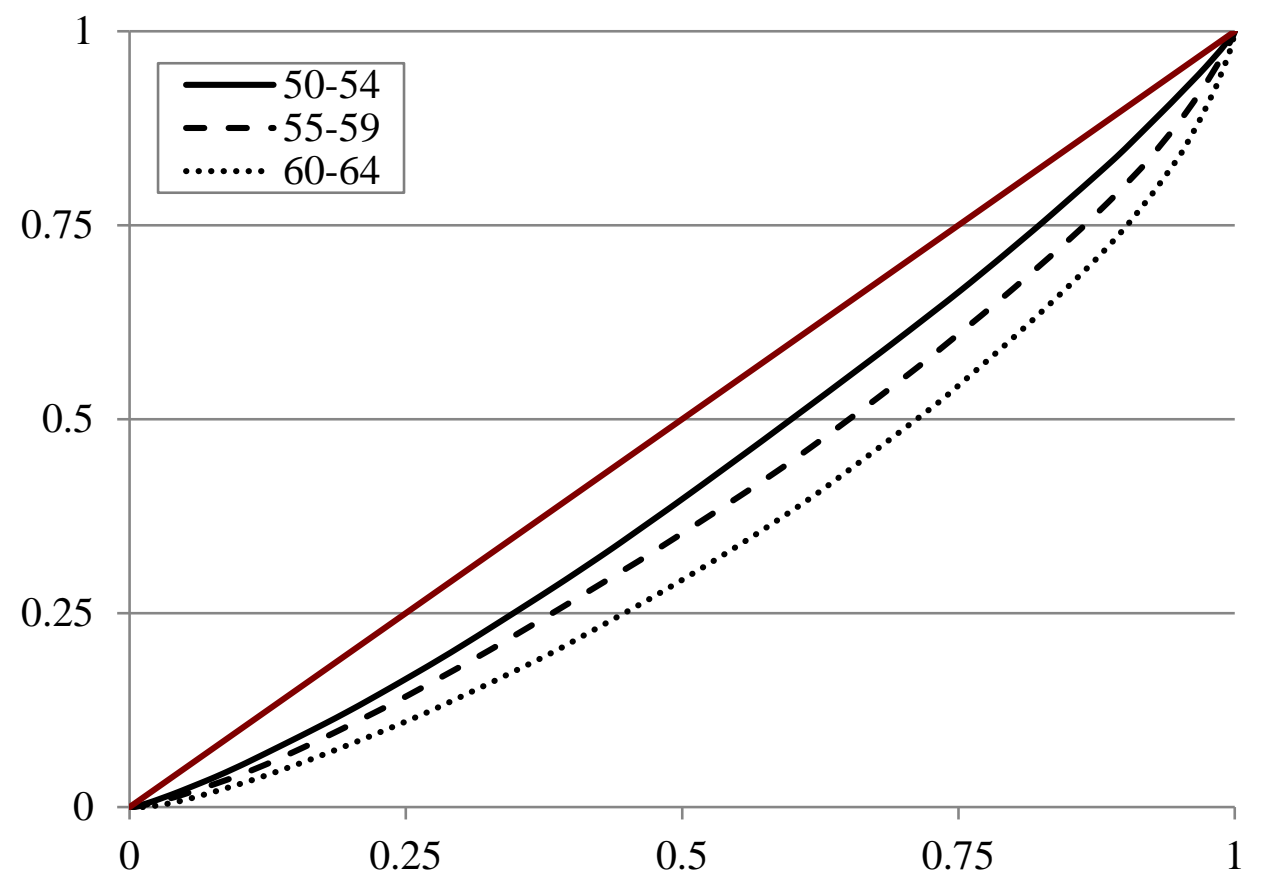

Source: Authors' calculations. 
Figure 4a. Lorenz Curves for Better-Educated Men

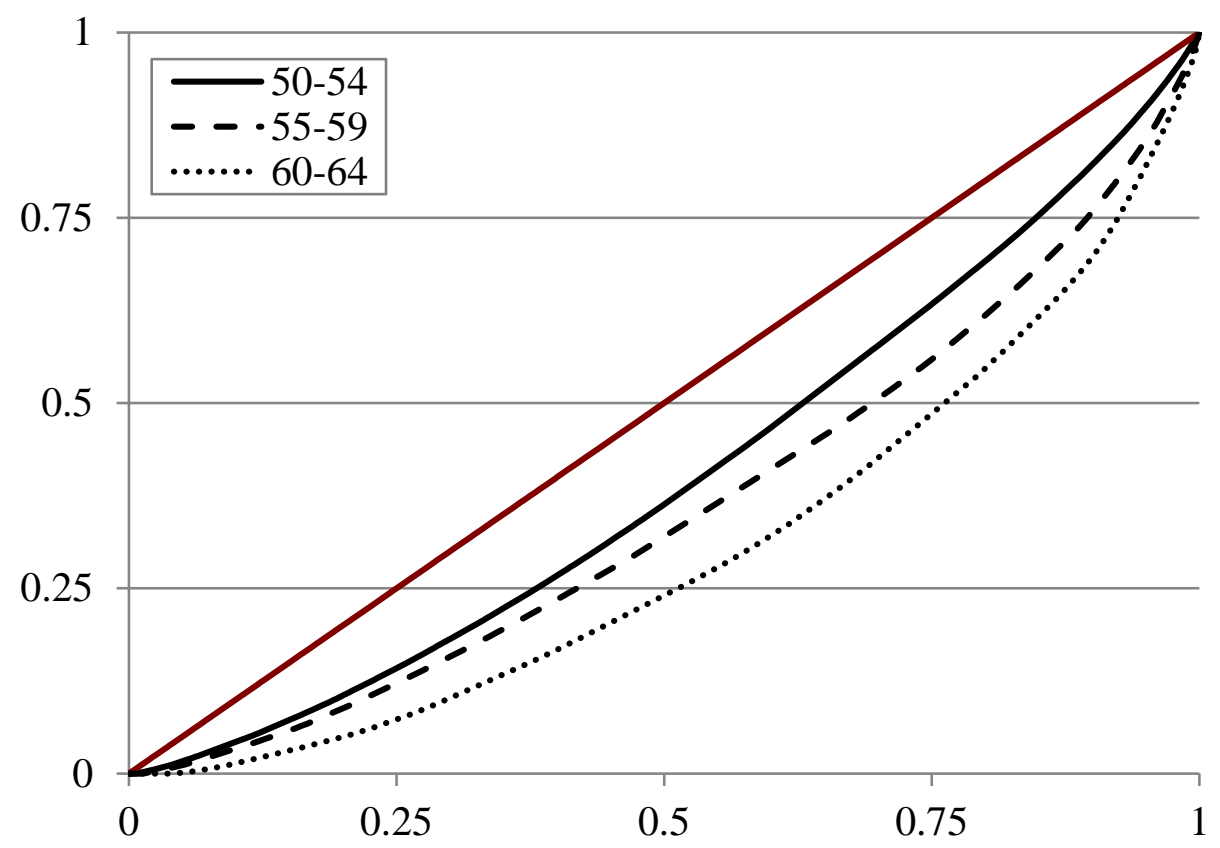

Source: Authors' calculations.

Figure 4b. Lorenz Curves for Less-Educated Men

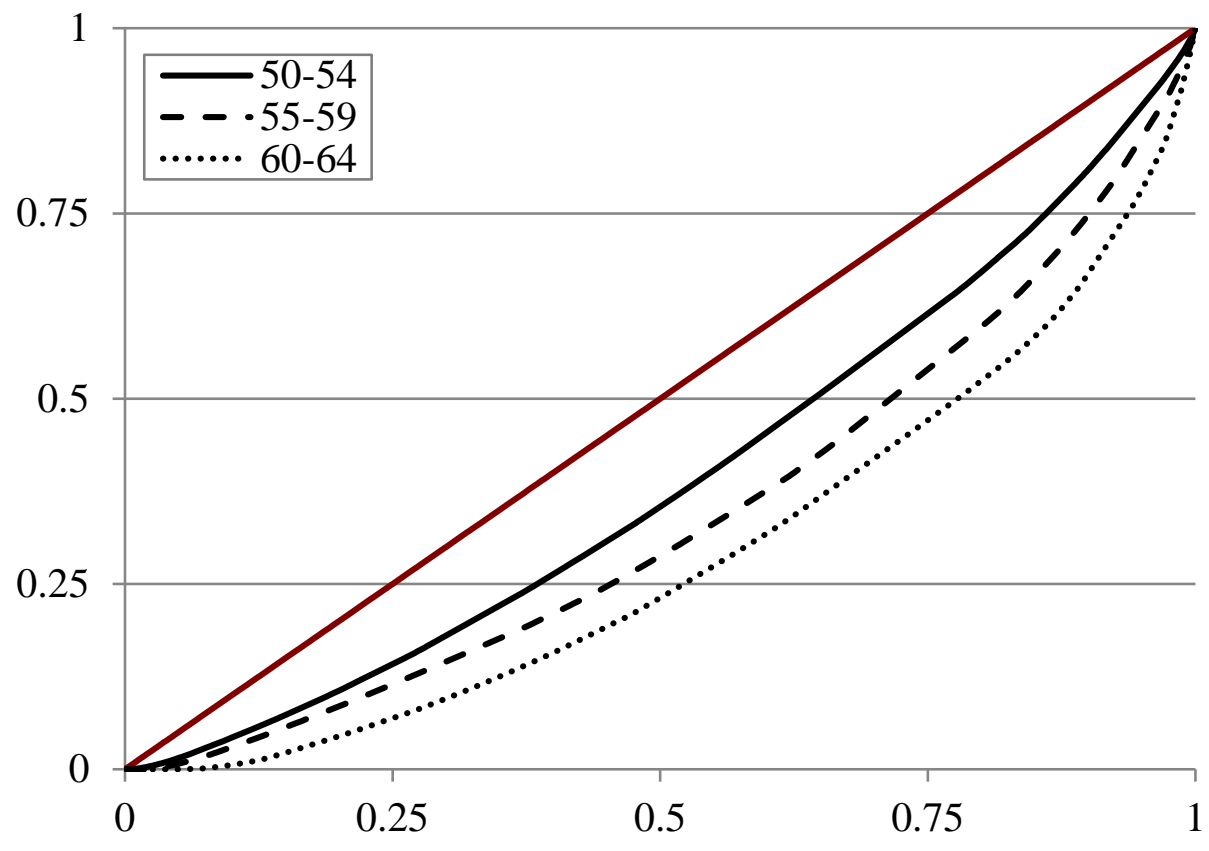

Source: Authors' calculations. 
Figure 5a. Lorenz Curves for Better-Educated Women

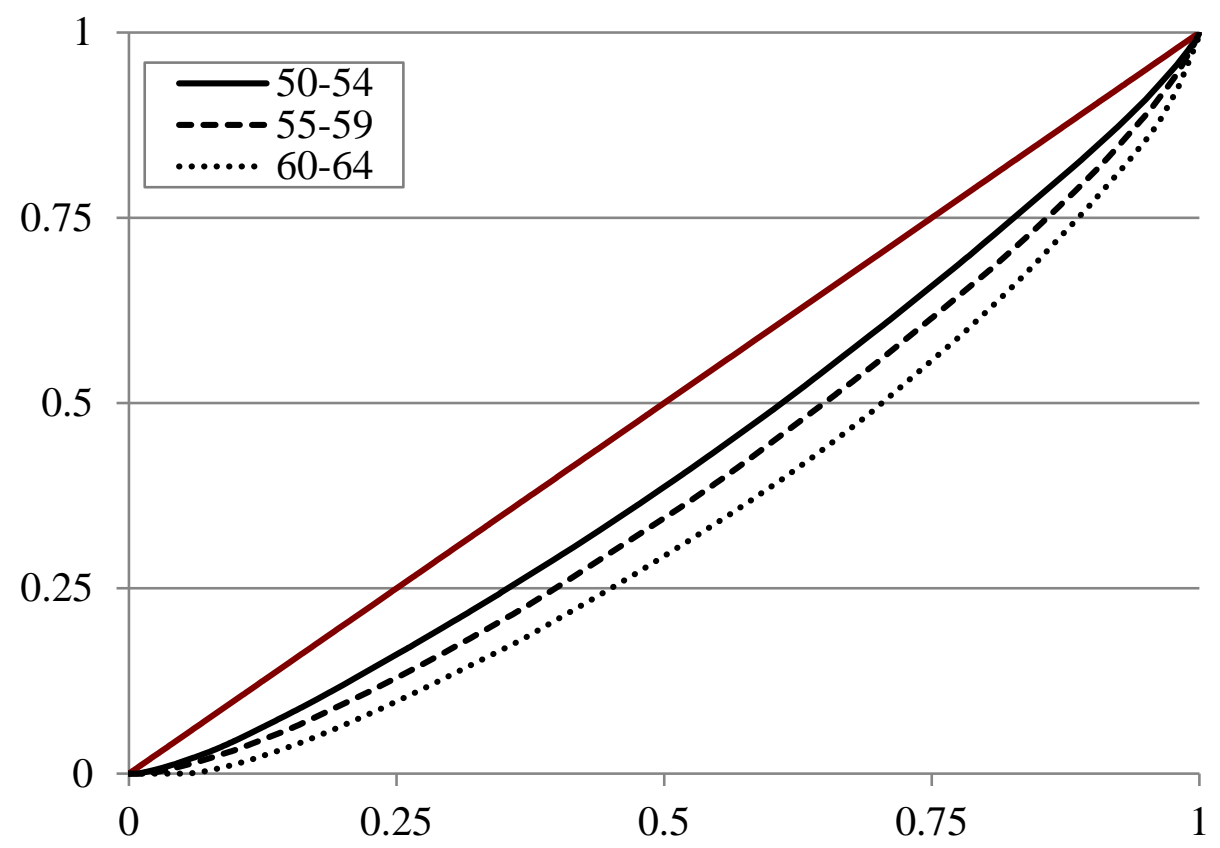

Source: Authors’ calculations.

Figure 5b. Lorenz Curves for Less-Educated Women

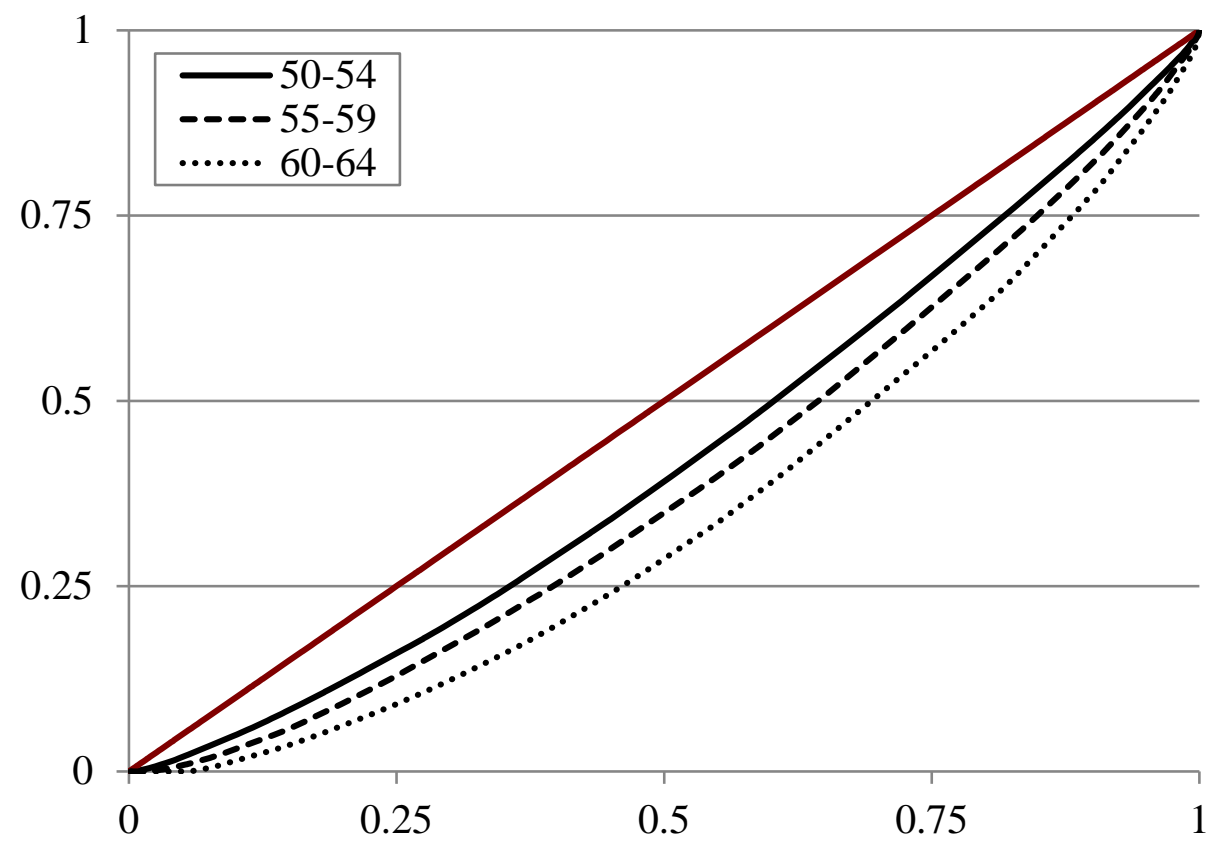

Source: Authors' calculations. 


\section{RECENT WORKING PAPERS FROM THE CENTER FOR RETIREMENT RESEARCH AT BOSTON COLLEGE}

How Much Longer Do People Need to Work?

Alicia H. Munnell, Anthony Webb, and Anqi Chen, August 2015

The Challenge of Pension Reform in Georgia: Non-Contributory Pensions and Elderly Poverty

Tamila Nutsubidze and Khatuna Nutsubidze, July 2015

The Transition from Defined Benefit to Defined Contribution Pensions: Does It Influence Elderly Poverty?

Natalia S. Orlova, Matthew S. Rutledge, and April Yanyuan Wu, July 2015

Will the Average Retirement Age Continue to Increase?

Matthew S. Rutledge, Christopher M. Gillis, and Anthony Webb, July 2015

The Role of Occupations in Differentiating Health Trajectories in Later Life Michal Engelman and Heide Jackson, University of Wisconsin-Madison, July 2015

The Relationship Between Automatic Enrollment and DC Plan Contributions: Evidence from a National Survey of Older Workers

Barbara A. Butrica and Nadia S. Karamcheva, July 2015

Evidence of Increasing Differential Mortality: A Comparison of the HRS and SIPP Barry P. Bosworth and Kan Zhang, July 2015

Slowed or Sidelined? The Effect of "Normal” Cognitive Decline on Job Performance Among the Elderly

Anek Belbase, Mashfiqur R. Khan, Alicia H. Munnell, and Anthony Webb, June 2015

Does Social Security Continue to Favor Couples?

Nadia S. Karamcheva, April Yanyuan Wu, and Alicia H. Munnell, June 2015

Sources of Increasing Differential Mortality Among the Aged by Socioeconomic Status Barry P. Bosworth, Gary Burtless, and Kan Zhang, June 2015

Do Retired Americans Annuitize Too Little? Trends in the Share of Annuitized Income Barry P. Bosworth, Gary Burtless, and Mattan Alalouf, June 2015

Impact of the Financial Crisis on Long-Term Growth Barry P. Bosworth, June 2015

All working papers are available on the Center for Retirement Research website (http://crr.bc.edu) and can be requested by e-mail (crr@bc.edu) or phone (617-552-1762). 